\title{
Kinetic Modelling of Betalain Stability and Color Changes in Yogurt During Storage
}

\author{
Onur Guneser ${ }^{(0)}$ \\ Department of Food Engineering, Engineering Faculty, Uşak University, 1 Eylül Campus, 64000, Uşak-Turkey
}

Key words: natural pigments, betalains, yogurt, reaction kinetics, color

Assessment of the storage stability of betalains added to food during processing is crucial to estimate the shelf-life of colored food products and the potency of natural food colorants. The stability of beetroot betalains in yogurt during storage was evaluated in this study. Kinetic experiments were conducted at storage temperatures of $4{ }^{\circ} \mathrm{C}, 10^{\circ} \mathrm{C}$, and $20^{\circ} \mathrm{C}$. The relationships were also determined between the betalain degradation and lightness $\left(L^{*}\right)$, redness $\left(a^{*}\right)$, and yellowness $\left(b^{*}\right)$. First-order kinetics was observed in the betalain degradation, and the changes in color parameters of the yogurt samples fitted zero-order kinetics. The activation energy required for the degradation of betalains and changes in $L^{*}, a^{*}$, and $b^{*}$ was found as 104.9 , 67.6, 76.5, and $86.1 \mathrm{~kJ} / \mathrm{mol}$, respectively. The half-life period of the degradation of red beet betalains was found as $51.43,30.91$, and 4.54 days at $4^{\circ} \mathrm{C}$, $10^{\circ} \mathrm{C}$, and $20^{\circ} \mathrm{C}$, respectively. Multiple linear regression models were also established for betalain content and color parameters. There was a decrease in betalain content and $a^{*}$ color value in the yogurt colored with a beetroot extract during storage. A significant positive correlation was found between $\mathrm{pH}, a^{*}$ value, and betalain content in yogurt, while a significant negative correlation was found between betalain content and $L^{*}$ and $b^{*}$ values. Further studies need to be carried out to reveal the relationship between color parameters and natural pigments in food systems.

\section{INTRODUCTION}

Since the last decade, natural pigments have attracted attention of the manufacturers in the food industry. The trend has shifted from artificial colorants to natural pigments owing to scientific studies regarding the potential risks of synthetic colorants to consumer health. At present, many scientific studies are being performed on natural pigments, and food manufacturers are trying to use them in food systems [Amchova et al., 2015; Galaffu et al., 2015]. Anthocyanins are the most studied natural pigments originating from plants, while betalains, carotenoids, chlorophylls, and curcumin are some other natural pigments that also offer beneficial health effects, such as preventing obesity [Martins et al., 2016].

Betalains are heterocyclic derivatives of betalamic acids. They are divided into two categories, namely: betacyanins and betaxanthins. Betacyanins exhibit red to purple hues, while betaxanthins exhibit yellow to orange hues. Beetroot (Beta vulgaris L. ssp. vulgaris), colored Swiss chard (B. vulgaris L. ssp. cicla), amaranth (Amarathus sp.), cactus fruit (Opuntia sp.), pitayas (Stenocereu ssp.), and pitahayas (Hylocereus undatus) are the main plant sources of betalains. Amanita muscaria (fly agaric, a higher fungus) is also their natural source [Azeredo, 2009; Bárta et al., 2020; Delgado-Vargas et al., 2000; Gengatharan et al., 2015]. Betalains have also gained interest owing to their health-promoting properties such as anti-atherogenic, anti-carcinogenic, anti-inflammatory, and hypolipidemic activities, along with colorant properties in food applications [Bárta et al., 2020; Delgado-Vargas et al., 2000; Moreno et al., 2008]. Red beetroot is the commercial source of red colored betalains including betanin and isobetanin. Therefore, a beetroot extract or/and juice concentrate is used as a food colorant in many food products, such as dairy-based snacks, with E number 162 (E-162) [Azeredo, 2009; Herbach et al., 2006].

Although the potential use of natural pigments is high, their application in foods is limited due to their low stability, weak tinctorial strength, strong interactions with food ingredients, and inability to match desired hues [Sigurdson et al., 2017]. In this context, although betalains have certain pharmacological activities and color properties, it can be said that their main drawback is their strong earth-like aroma. Several types of studies are ongoing for their applicability in food systems using various techniques, such as co-pigmentation. Betalains as natural colorants in real food systems are less explored. A recent study [Gengatharan et al., 2017] has shown the effects of $\mathrm{pH}$ and refrigerated storage on the stability of a colorant extract obtained from red pitahaya in yogurt. The degradation rate of betacyanin in yogurts containing the colorant extract at 14 days of refrigerated storage was $1.0 \%$, while a loss of $1.6 \%$ betacyanin was observed in yogurt colored with a commercial

\footnotetext{
* Corresponding Author: Tel: +90 2762212121 Ext: 2754;

E-mail: onur.guneser@usak.edu.tr (Dr. O. Guneser)
} 
colorant E-162. This study also showed that the extract from red pitahaya treated at $\mathrm{pH} 4$ and 5 caused a lower reduction of betacyanins compared to E-162 in yogurt during ten weeks of refrigerated storage at $4^{\circ} \mathrm{C}$.

Betalains are stable at $\mathrm{pH}$ ranging from 3 to 7 compared with anthocyanins, and are suitable coloring agents that can be stabilized by ascorbic acid [Sigurdson et al., 2017]. Herbach et al. [2007] reported that the betacyanins present in purple pitaya (Hylocereus polyrhizus) could be easily stabilized by $1 \%$ ascorbic acid. In contrast, Karangutkar \& Ananthanarayan [2021] found that $0.05 \%$ of ascorbic acid reduced betacyanin content in Basella rubra in a model beverage system during storage because of its pro-oxidant effect. Moreover, the addition of $5 \mathrm{mM}(+)$-catechin in a model beverage system was found to fulfill the maximum pigment retention at low temperature $\left(4^{\circ} \mathrm{C}\right)$, and in the absence of light and oxygen.

Assessment of the thermal and storage stabilities of betalains added in real food systems during processing is crucial to estimate the shelf-life of colored food products and the potency of natural food colorants [Güneşer, 2016]. This study aimed to evaluate the stabilities of beetroot betalains in yogurt during storage at $4^{\circ} \mathrm{C}, 10^{\circ} \mathrm{C}$, and $20^{\circ} \mathrm{C}$ using a chemical kinetics approach. The relationships between betalain content, color parameters, and $\mathrm{pH}$ during storage were determined using multiple linear regression and correlation analyses.

\section{MATERIALS AND METHODS}

\section{Materials}

Beetroot betalains used in the present study were acquired from a commercial natural liquid colorant from beetroot (Wild Flavors, ADM Wild GmbH, Eppelheim, Germany) that was obtained from NANTE Chemical Company (Istanbul, Turkey). Cow milk for yogurt production was obtained from a local producer (Usak, Turkey). The yogurt starter culture (Büyüyo Yogurt Culture, a mixed culture of Lactobacillus delbrueckii ssp. bulgaricus + Streptococcus thermophiles + Lactobacillus acidophilus) was obtained from Danem Dairy Company (Isparta, Turkey). All chemicals were of analytical/chromatographic grade and were purchased from Merck (Darmstadt, Germany) and Sigma-Aldrich (St. Louis, MO, USA).

\section{Production of yogurt with beetroot betalains}

Yogurt was prepared according to the procedure of Yiğit et al. [2011]. Cow milk (6 L) was blended using a hand blender to get a homogeneous matrix. Then, the milk was distributed in three glass jars. The glass jars were placed in a water bath and heated to $85 \pm 2^{\circ} \mathrm{C}$ for $30 \mathrm{~min}$. Then, they were placed in an ice-water bath for cooling. When the temperature of the glass jars had reached at $43 \pm 2^{\circ} \mathrm{C}$, the beetroot colorant $(3 \mathrm{~g} / \mathrm{L})$ and the yogurt starter culture $(0.25 \mathrm{~g} / \mathrm{L})$ were added into each glass jar aseptically and then mixed by a hand blender at a medium speed ( $2 \mathrm{~g}$ force). The inoculated milk was poured into 100-g plastic cups (polypropylene) with lids (polyethylene terephthalate) and incubated at $43 \pm 2^{\circ} \mathrm{C}$ in an incubator (Nüve-ES 120, Ankara, Turkey) until $\mathrm{pH}=4.7$. After incubation, the yogurt samples were immediately shifted to refrigerated incubators for further experimentation. The procedures for the preparation of the yogurt samples were established based on the standard yogurt production steps [Tamime \& Robinson, 2007]. Yogurt production was performed in duplicate. The amount of commercial beetroot colorant added into yogurt was determined by pre-coloring experiments and the recommendations of the producer. Moreover, in the Turkish Food Codex [TFC, 2013], the limit of beetroot colorant use was determined as a quantum satis. The inoculation rate of the yogurt culture was based on the recommendations of the Danem Dairy Company.

\section{Storage experiment}

The storage stability and changes in the color parameters of beetroot betalains in yogurt were examined at $4^{\circ} \mathrm{C}, 10^{\circ} \mathrm{C}$, and $20^{\circ} \mathrm{C}$ for 60,40 , and 20 days, respectively, in refrigerated incubators (Nüve-ES 120, Ankara, Turkey and Memmert IPP500, Schwabach, Germany). The temperatures for yogurt storage were chosen by considering possible facilities such as transport, storage, and retail temperature conditions that consumers and manufacturers generally use for yogurt $\left(4^{\circ} \mathrm{C}\right.$ as storage temperature, $10^{\circ} \mathrm{C}$ as refrigerator temperature, and $20^{\circ} \mathrm{C}$ as cool ambient temperature). During storage, the yogurt samples were taken at regular time intervals (8-day for $4^{\circ} \mathrm{C}$; 4-day for $10^{\circ} \mathrm{C}$; and 2-day for $20^{\circ} \mathrm{C}$ ) for chemical and color analyses, which were performed in duplicate for each storage temperature.

\section{Titratable acidity, pH, and proximate analysis}

Physicochemical properties of the yogurt samples, including $\mathrm{pH}$, titratable acidity (g lactic acid/100g), total solids $(\mathrm{g} / 100 \mathrm{~g})$, contents of fat $(\mathrm{g} / 100 \mathrm{~g})$, protein $(\mathrm{g} / 100 \mathrm{~g})$, and ash $(\mathrm{g} / 100 \mathrm{~g})$ were determined by the methods described by Bradley et al. [1992].

\section{Determination of betalain content in yogurts during storage}

The betalain fraction was separated from yogurt samples using the method proposed by Gandía-Herrero et al. [2012] . In brief, $10 \mathrm{~g}$ of yogurt was centrifuged at $3075 \times \mathrm{g}$ in a falcon tube at $10^{\circ} \mathrm{C}$, and next the upper part was filtrated using a $0.45 \mu$ PTFE syringe filter. Using this separation method, the recovery rate was $>95 \%$. Quantification of betalains (betanin+iso-betanin) in the yogurt fraction was performed by the HPLC with the external standard method [Naderi et al., 2012]. The Agilent 1260 HPLC system with Agilent multiple wavelength UV detector (Agilent Technologies Inc., Folsom, CA, USA) was used. Separation of betalains was carried out using a Zorbax SB-C18 column (Agilent, $4.6 \times 250 \mathrm{~mm}$, particle size of $5 \mu \mathrm{m}$ ). The mobile phase consisted of $0.5 \mathrm{~mL} / \mathrm{L}$ trifluoroacetic acid solution and acetonitrile (90:10). The flow rate was kept constant at $1.0 \mathrm{~mL} / \mathrm{min}$, and the column temperature was maintained at $20^{\circ} \mathrm{C}$ for a total run. The detector was set at $540 \mathrm{~nm}$ for monitoring betalains. Betanin (product no: 901266, Sigma-Aldrich, St. Louis, MO, USA) was used as an external standard. The limit of detection, the limit of quantification, and repeatability were determined to be $7.12 \mathrm{mg} / \mathrm{kg}, 23.75 \mathrm{mg} / \mathrm{kg}$, and $1.05 \%$, respectively. The content of betalains in yogurts was expressed as $\mathrm{mg} / \mathrm{kg}$ yogurt. 


\section{Measurement of color parameters}

The color parameters $\left(L^{*}-\right.$ lightness, $a^{*}-$ redness and $b^{*}-$ yellowness) of the yogurts were measured by using Minolta Cr-400 colorimeter (Minolta Co. Ltd., Osaka, Japan). A standard white plate was used for colorimeter calibration. Standard illuminant $\mathrm{C}$ and a standard observer angle $\left(2^{\circ}\right)$ were used for color measurements [ISO-CIE, 2008; Wrolstad $\&$ Smith, 2017]. The measurement was taken twice per sample.

\section{Calculation of kinetic parameters}

The storage stability of betalains and changes in color parameters of the yogurt samples during storage were evaluated using kinetic parameters (reaction order, reaction rate constants $(k)$, and half-life period $\left.\left(t_{1 / 2}\right)\right)$. The effect of temperature on betalain degradation was studied and expressed by both activation energy $\left(E_{\mathrm{a}}\right)$ and temperature quotient $\left(Q_{10}\right)$ [van Boekel, 2008].

\section{Statistical analysis}

Pearson's correlation and multiple regression analysis were performed to evaluate the relationship between the color parameters and betalain content of the yogurts [Sheskin, 2004]. SPSS software version 15.0 for Windows (IBM, Armonk, NY, USA) was used for the statistical analysis.

\section{RESULTS AND DISCUSSIONS}

\section{Proximate composition, $\mathrm{pH}$, and titratable acidity of the fresh yogurt}

The stability of several natural pigments is affected by the physicochemical characteristics of food containing them. Therefore, the proximate composition of the fresh yogurt was determined, and the results are given in Table 1. The yogurt contained $13.13 \mathrm{~g} / 100 \mathrm{~g}$ of dry matter and $2.50 \mathrm{~g} / 100 \mathrm{~g}$ of fat, while about $3.01 \mathrm{~g} / 100 \mathrm{~g}$ of protein and $0.85 \mathrm{~g} / 100 \mathrm{~g}$ of ash on average. Its $\mathrm{pH}$ was about 4.53 and its titratable acidity was $0.81 \mathrm{~g}$ lactic acid/100 g. The chemical composition of yogurt may be affected by many factors, such as milk composition, presence of additives, process types, etc. The chemical composition of the fresh yogurt in the present study was typical of this kind of product, as supported by the results of previous studies [Özoğlu et al., 2020; Yiğit et al., 2011]. Özoğlu et al. [2020] investigated proximate compositions of homemade probiotic and commercial non-probiotic yogurts. They found that the $\mathrm{pH}$ values and dry matter contents of the yogurts were at 4.45-4.48 and 11.25-11.45 g/100 g, respectively. Protein and fat contents of the yogurts were found to range between 2.95 and 4.0, and between 3.01 and $3.70 \mathrm{~g} / 100 \mathrm{~g}$, respectively. Similarly, Farinde et al. [2009] reported $15.9 \mathrm{~g} / 100 \mathrm{~g}$ of dry matter, $2.4 \mathrm{~g} / 100 \mathrm{~g}$ of protein, and $0.4 \mathrm{~g} / 100 \mathrm{~g}$ of ash contents for the commercial cow's milk yogurts sold in Nigeria. Hence, an average $\mathrm{pH}$ and acidity values of the yogurts were determined as 4.1 and $0.1 \mathrm{~g}$ lactic acid $/ 100 \mathrm{~g}$, respectively. The moisture content of the yogurt samples ranged from $83.3 \%$ in cow's milk

\section{Changes of yogurt $\mathrm{pH}$ and titratable acidity during storage}

In the present study, the $\mathrm{pH}$ and titratable acidity of yogurts during storage were also monitored. The $\mathrm{pH}$ of yogurt
TABLE 1. Proximate composition, $\mathrm{pH}$, and titratable acidity of the fresh yogurt.

\begin{tabular}{lc}
\hline Parameter & Value \\
\hline $\mathrm{pH}$ & $4.53 \pm 0.12$ \\
Titratable acidity $(\mathrm{g}$ lactic acid/100 g) & $0.81 \pm 0.05$ \\
Dry matter content $(\mathrm{g} / 100 \mathrm{~g})$ & $13.13 \pm 0.02$ \\
Fat content $(\mathrm{g} / 100 \mathrm{~g})$ & $3.01 \pm 0.01$ \\
Protein content $(\mathrm{g} / 100 \mathrm{~g})$ & $2.50 \pm 0.01$ \\
Ash content $(\mathrm{g} / 100 \mathrm{~g})$ & $0.85 \pm 0.01$ \\
\hline
\end{tabular}

The values are expressed as means \pm standard deviation (SD).

decreased significantly during storage at all storage temperatures (Figure 1). The $\mathrm{pH}$ decrease was higher at $20^{\circ} \mathrm{C}$ than at other storage temperatures probably due to the higher metabolic activity of lactic acid bacteria at this temperature, as indicated by titratable acidity (Table 2). Increasing acidity in yogurt during storage is known as a post-acidification effect caused by the metabolic activities of lactic acid bacteria that produce lactic acid, and decreasing the shelf-life of yogurt [Shah, 2000].

\section{Storage stability of betalains and changes in color parameters of yogurts}

The chromatographic separations of betalains in the yogurts are shown in Figure 2. Two betalains were identified in the yogurts colored with beetroot colorants. The peak 1 with retention time of $10.53 \mathrm{~min}$ corresponds to betanin, while the second peak with retention time of $14.04 \mathrm{~min}$ to iso-betanin (Figure 2). Moreover, betanin and iso-betanin are predominant betalains in beet root, as mentioned before. The findings of the present study are in good agreement with the literature data [Azeredo, 2009; Herbach et al., 2006]. The content of betalains in the yogurts stored at $4-20^{\circ} \mathrm{C}$ is provided in Figure 3. It was $305.18 \mathrm{mg} / \mathrm{kg}$ of the fresh yogurt and decreased during storage by $49.36 \%, 58.55 \%$, and $95.65 \%$ at $4^{\circ} \mathrm{C}, 10^{\circ} \mathrm{C}$, and $20^{\circ} \mathrm{C}$, respectively.

The degradation of betalains followed the first-order reaction kinetics with high determination coefficients $\left(\mathrm{R}^{2}=0.983,0.971\right.$ and 0.969 at $4^{\circ} \mathrm{C}, 10^{\circ} \mathrm{C}$, and $20^{\circ} \mathrm{C}$, respectively). Kinetic parameters for the degradation of betalains are given in Table 3. The $k$ values were found in the range from $-13.4 \times 10^{-3} /$ day to $-152.3 \times 10^{-3} /$ day. The degradation rate of betalains in the yogurt samples increased with the elevation of storage temperature. This finding was confirmed by the half-life $\left(t_{1 / 2}\right)$ values. Values $t_{1 / 2}$ for betalains in the yogurt samples were found to be $51.43,30.91$, and 4.54 days at $4^{\circ} \mathrm{C}, 10^{\circ} \mathrm{C}$, and $20^{\circ} \mathrm{C}$, respectively. Similarly to present findings, several studies have described the first-order kinetics of betalain degradation in different types of food under various storage and process conditions [Caldas-Cueva et al., 2016; Kayın et al., 2019; Tobolková et al., 2020]. Kayın et al. [2019] reported the first-order kinetics for betacyanin and betaxanthin degradations in red beet juice concentrates stored in glass jars with and without aluminum foil at $25-45^{\circ} \mathrm{C}$. 


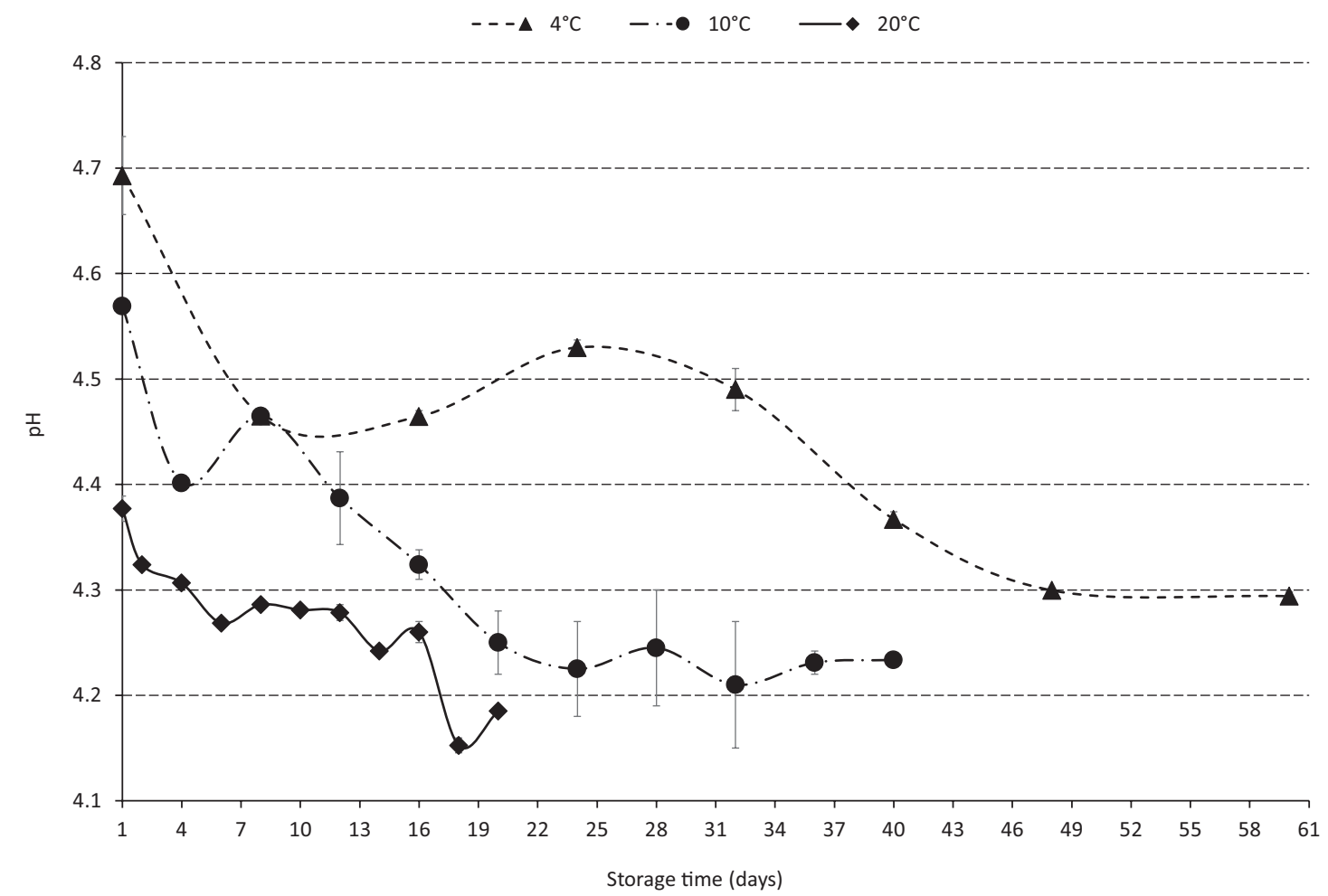

FIGURE 1 . The $\mathrm{pH}$ value of the yogurts stored at $4-20^{\circ} \mathrm{C}$.

The error bars represent the standard error.

TABLE 2. Titratable acidity (g lactic acid/100 g) of the stored yogurts.

\begin{tabular}{c|c|c|c}
\hline \multirow{2}{*}{$\begin{array}{c}\text { Storage } \\
\text { time (day) }\end{array}$} & \multicolumn{3}{|c}{ Temperature $\left({ }^{\circ} \mathrm{C}\right)$} \\
\cline { 2 - 4 } & 4 & 10 & 20 \\
\hline 1 & $0.75 \pm 0.01$ & $0.80 \pm 0.01$ & $0.89 \pm 0.01$ \\
2 & $-^{*}$ & - & $0.98 \pm 0.05$ \\
4 & - & $0.84 \pm 0.03$ & $0.97 \pm 0.01$ \\
6 & - & - & $0.96 \pm 0.01$ \\
8 & $0.82 \pm 0.02$ & $0.92 \pm 0.01$ & $1.01 \pm 0.01$ \\
10 & - & - & $1.03 \pm 0.01$ \\
12 & - & $0.99 \pm 0.01$ & $0.99 \pm 0.01$ \\
14 & - & - & $1.02 \pm 0.01$ \\
16 & $0.92 \pm 0.02$ & $0.91 \pm 0.02$ & $0.96 \pm 0.04$ \\
18 & - & - & $1.03 \pm 0.02$ \\
20 & - & $0.92 \pm 0.01$ & $1.01 \pm 0.01$ \\
24 & $0.91 \pm 0.13$ & $0.92 \pm 0.01$ & - \\
28 & - & $0.99 \pm 0.01$ & - \\
32 & $0.90 \pm 0.01$ & $0.95 \pm 0.01$ & - \\
36 & - & $1.01 \pm 0.01$ & - \\
40 & $0.86 \pm 0.01$ & $0.90 \pm 0.04$ & - \\
48 & $0.90 \pm 0.01$ & - & - \\
60 & $0.91 \pm 0.01$ & - & - \\
\hline
\end{tabular}

*Analysis was not conducted on particular days. The values are expressed as means \pm standard error (SE).
They calculated $k$ values reaching $14.8 \times 10^{-3} /$ day, $29.4 \times 10^{-3} /$ day, and $79.5 \times 10^{-3} /$ day for betacyanin degradation at $25^{\circ} \mathrm{C}$, $35^{\circ} \mathrm{C}$, and $45^{\circ} \mathrm{C}$, respectively, whereas low $k$ values, such as $8.5 \times 10^{-3} /$ day, $37.1 \times 10^{-3} /$ day, and $90.2 \times 10^{-3} /$ day, were calculated for betaxanthin degradation at the same storage temperatures.

In another study by Tobolková et al. [2020], the first-order reaction was observed for the degradation of both betacyanins and betaxanthins in apple-beetroot juice stored at $2^{\circ} \mathrm{C}$, $7^{\circ} \mathrm{C}$, and $20^{\circ} \mathrm{C}$. The $k$ values for betacyanin and betaxanthin degradations ranged from $7.3 \times 10^{-3} /$ day to $47.1 \times 10^{-3} /$ day and from $6.4 \times 10^{-3} /$ day to $28.5 \times 10^{-3}$ /day, respectively, which were lower than those observed in the present study. Similarly, Caldas-Cueva et al. [2016] reported that the degradation of betacyanins of an ayrampo (Opuntia soehrensii) seed extract and a red beet extract during the storage at $4^{\circ} \mathrm{C}$ and $25^{\circ} \mathrm{C}$, at $\mathrm{pH} 4.5$ followed the first-order reactions kinetics. The stability of betacyanins in the ayrampo seed extract was higher than that in the red beet extract at both temperatures tested. Color retention in yogurts containing the ayrampo seed extract and the red beet extract was not influenced by fat content, and the ayrampo seed extract showed better color retention over 4-week storage at $4^{\circ} \mathrm{C}$ compared with the red beet extract. Contrary to present findings, Moreno et al. [2007] reported the zero-order reaction for the degradation of betalains from tuna (Opuntia elatior Miller) and beetroot (Beta vulgaris L.) in four different citrus beverage formulations during storage at $7^{\circ} \mathrm{C}$, with $k$ values between 12.4 and $18.1 \mathrm{~g} / 100 \mathrm{~mL} \times$ day.

The differences in findings on betalain degradation could be attributed to the differences in the structure 


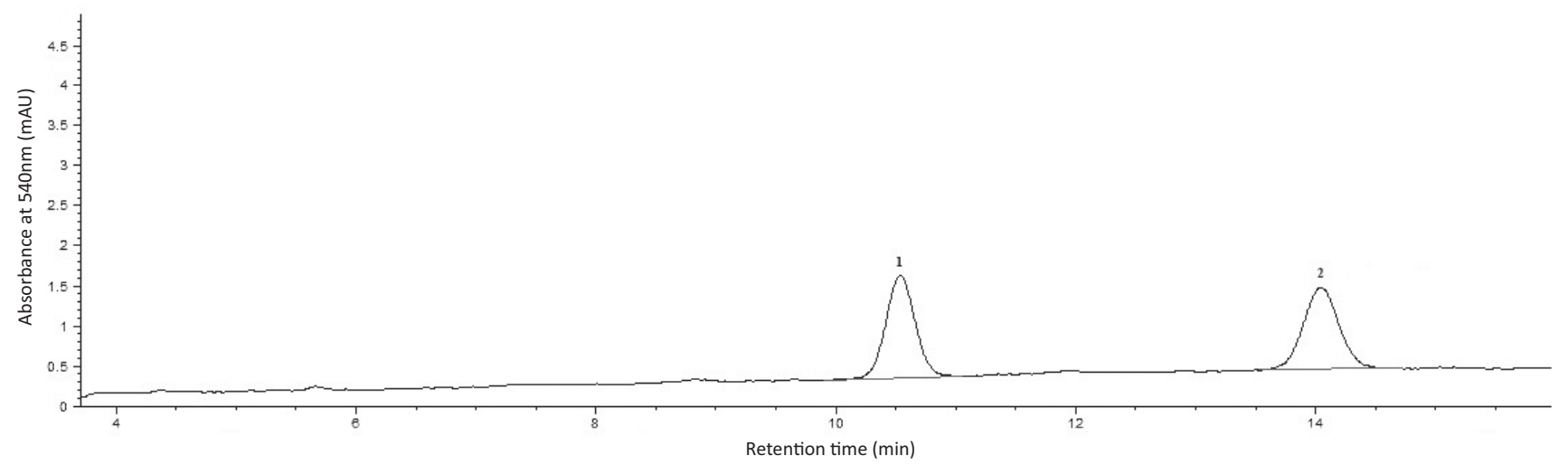

FIGURE 2. HPLC separation of the betalain fraction from yogurt with a red beet colorant. Peaks number 1 and 2 correspond to betanin and iso-betanin, respectively.

of individual betalains, food matrix and product formulation, process conditions, and storage temperatures [Azeredo et al., 2009; Khan, 2006]. Many types of reactions, such as hydrolysis, drive the degradation of betalains [Manchali et al., 2013]. Each reaction that has different responses regarding chemical kinetics occurs by various chemical mechanisms and depends on many factors. Betalains are considered as heat-labile pigments. Many researchers have reported [Herbach et al., 2004, 2007; Kayin et al., 2019] that their stability decreased by increasing temperature depending on pigment concentration, temperature level, exposure time of heating, or the presence of oxygen. It has been emphasized that betalains are considerably degraded between 50 and $75^{\circ} \mathrm{C}$ [Herbach et al., 2006; Manchali et al., 2013]. They may be also degraded by isomerization at low temperatures, and their chemical structure and color change as a result of isomerization reactions [Herbach et al., 2006]. Especially, betalains are transformed to the decarboxylated, dehydrogenated, or glycoside derivatives at high temperature. For instance, betanin (red) is conversed to neobetanin, which has yellow color, by dehydrogenation reaction, while 15-decarboxy-betanin (red), 17-decarboxy-betanin (orange-red), and cyclodopa-5-O-glycoside (colorless) are formed by the decarboxylation of betanin [Azeredo, 2009; Herbach et al., 2006; Khan, 2016; Manchali et al., 2013]. Fermentation was also determined to affect the stability of betalains. According to Czyżowska et al. [2006], betanidin and isobetanidin can be formed by izomerization in red beet juice during lactic acid fermentation. In addition, ratios of betanin +isobetanin/betanidin + isobetanidin, isobetanin/betanin, neobetanin/betanin, and vulgaxanthin $\mathrm{I} /$ betanin were found to change in the fermented red beet juice depending on the variety of beet processed (Czerwona Kula and Chrobry). The authors reported that these changes could be due to the activity of $\beta$-glucosidase sourced by lactic acid bacteria and the activities of certain

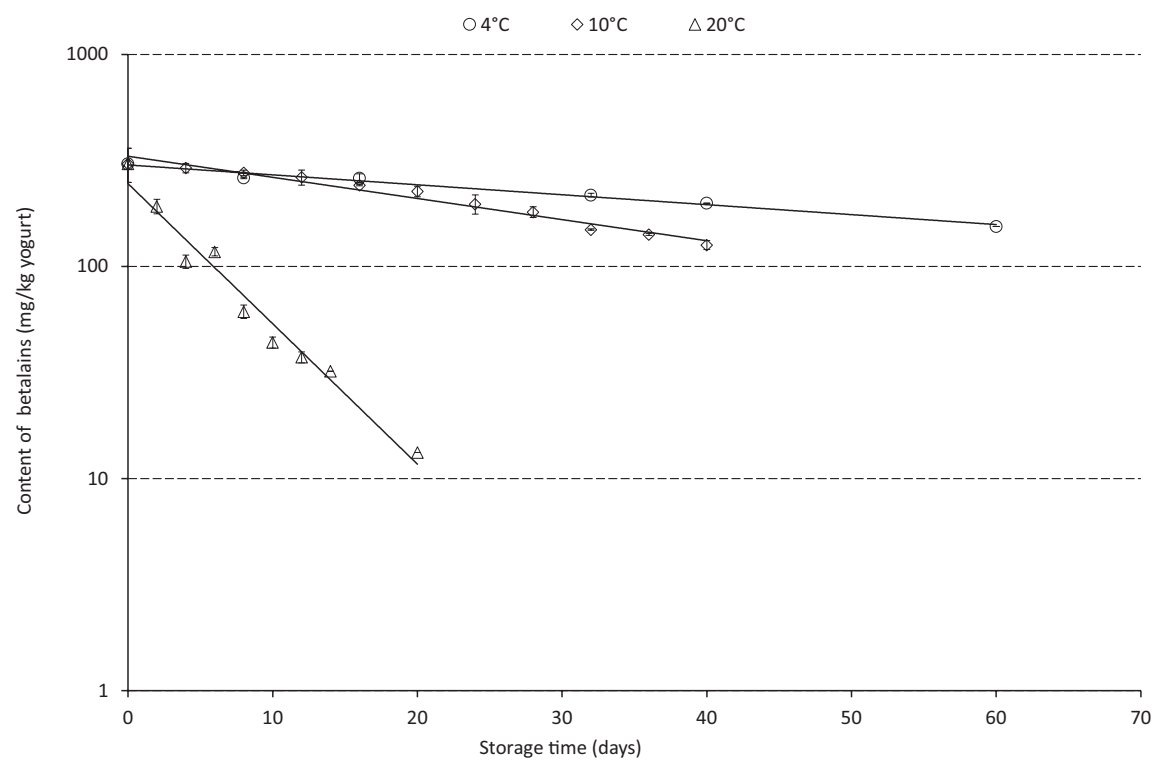

FIGURE 3. Betalain content in the yogurts stored at $4-20^{\circ} \mathrm{C}$.

The error bars represent the standard error. 
TABLE 3. The kinetic parameters determined for betalain degradation and for color parameter changes of the yogurts during storage.

\begin{tabular}{|c|c|c|c|c|c|c|c|}
\hline \multirow{2}{*}{ Parameter } & \multirow{2}{*}{$\begin{array}{l}\text { Temperature } \\
\left({ }^{\circ} \mathrm{C}\right)\end{array}$} & \multirow{2}{*}{$\begin{array}{l}\text { Reaction } \\
\text { order }\end{array}$} & \multirow{2}{*}{ Reaction rate constant $(k)$} & \multirow{2}{*}{$\begin{array}{c}t_{1 / 2} \\
\text { (day) }\end{array}$} & \multirow{2}{*}{$\begin{array}{l}\text { Activation energy }\left(E_{\mathrm{a}}\right) \\
(\mathrm{kJ} / \mathrm{mol})\end{array}$} & \multicolumn{2}{|c|}{$Q_{10}$} \\
\hline & & & & & & $4-10^{\circ} \mathrm{C}$ & $10-20^{\circ} \mathrm{C}$ \\
\hline \multicolumn{8}{|c|}{$\times 10^{-3}(1 /$ day $)$} \\
\hline \multirow{3}{*}{$\begin{array}{l}\text { Betalain } \\
\text { content }\end{array}$} & 4 & & $-13.4 \pm 0.1(0.983)^{\mathrm{a}}$ & 51.43 & & & \\
\hline & 10 & First-order & $-23.0 \pm 0.9(0.971)$ & 30.91 & $104.9 \pm 0.1(0.966)$ & 2.43 & 6.61 \\
\hline & 20 & & $-152.3 \pm 0.1(0.969)$ & 4.54 & & & \\
\hline \multicolumn{8}{|c|}{$\times 10^{-3}\left(L^{*} /\right.$ day $)$} \\
\hline \multirow{3}{*}{$L^{*}$} & 4 & & $28.8 \pm 1.6(0.982)$ & $-\mathrm{b}$ & & & \\
\hline & 10 & Zero-order & $45.5 \pm 1.7(0.952)$ & - & $67.6 \pm 4.8(0.988)$ & 2.13 & 3.56 \\
\hline & 20 & & $162.1 \pm 8.7(0.852)$ & - & & & \\
\hline \multicolumn{8}{|c|}{$\times 10^{-3}\left(a^{*} /\right.$ day $)$} \\
\hline \multirow{3}{*}{$a^{*}$} & 4 & & $-53.3 \pm 0.8(0.958)$ & - & & & \\
\hline & 10 & Zero-order & $-95.6 \pm 7.5(0.982)$ & - & $76.5 \pm 0.6(0.994)$ & 2.63 & 3.35 \\
\hline & 20 & & $-321 \pm 1.4(0.948)$ & - & & & \\
\hline \multicolumn{8}{|c|}{$\times 10^{-3}\left(b^{*} /\right.$ day $)$} \\
\hline \multirow{3}{*}{$b^{*}$} & 4 & & $34.9 \pm 1.2(0.906)$ & - & & & \\
\hline & 10 & Zero-order & $69.7 \pm 6.5(0.958)$ & - & $86.1 \pm 1(0.990)$ & 3.15 & 3.76 \\
\hline & 20 & & $262.6 \pm 1.9(0.924)$ & - & & & \\
\hline
\end{tabular}

${ }^{a}$ Numbers in parentheses are determination coefficient $\left(\mathrm{R}^{2}\right)$. ${ }^{\text {Th }}$ The value was not calculated due to zero-order reaction. $L^{*}$ : lightness, $a^{*}$ : redness, $b^{*}$ : yellowness, $t_{1 / 2}$ : half-life, $Q_{10}$ : temperature quotient. The values are expressed as means \pm standard deviation (SD).

enzymes including dehydrogenase, polyphenoloxidases, or peroxidase, which were found in the red beet juice medium [Czyżowska et al., 2006].

Unlike the changes in betalain content of the yogurt samples, changes in $L^{*}, a^{*}$, and $b^{*}$ color parameters followed the zero-order kinetics during storage (Figure 4, Table 3). The $L^{*}$ and $b^{*}$ values increased, while the $a^{*}$ values decreased during yogurt storage at all storage temperatures. Furthermore, $k$ values determined for the changes in $L^{*}, a^{*}$, and $b^{*}$ values were found in the range between $28.8 \times 10^{-3}$ and $162.1 \times 10^{-3}$ $L^{*} /$ day; $-53.3 \times 10^{-3}$ and $-321 \times 10^{-3} a^{*} /$ day; as well as $34.9 \times 10^{-3}$ and $262.6 \times 10^{-3} b^{*} /$ day, respectively. According to this, the reaction rate determined for changes in the $a^{*}$ values of the yogurts stored at all temperatures was higher than those determined for the $L^{*}$ and $b^{*}$ values (Table 3 ). This can be attributed to the changes in chemical structures and spectral properties of betalains as a result of several reactions. Indeed, degradation of betalains led to an increase in $L^{*}, b^{*}$, and hue angle values and to a decrease in $a^{*}$ value, as commonly reported in previous research [Fernández-López et al., 2013; Gandia-Herrero et al., 2010; Herbach et al., 2004]. Different UV absorption and reflectance properties were reported for decarboxylated, dehydrogenated, or glycoside derivatives from betalains in different food matrices and solvents. According to this, betanin from red beet displays a maximum UV visible absorbance at $538 \mathrm{~nm}$, while its dehydrogenated derivatives (neobetanins) have the maximum UV absorbance at $477 \mathrm{~nm}$ [Herbach et al., 2004].
Although several works are available on the kinetics of changes in the color parameters of anthocyanins in various foods [Reyes \& Cisneros-Zevallos, 2007; Roidoung et al., 2017], studies regarding the kinetics of color changes of betalains are sparse. Kayın et al. [2019] reported that $L^{*}, a^{*}$, and $b^{*}$ value changes in a red beet juice concentrate stored at $25^{\circ} \mathrm{C}$, $35^{\circ} \mathrm{C}$, and $4^{\circ} \mathrm{C}$ followed the zero-order kinetics with $k$ values lower than that found in the present study. Sonar et al. [2019] reported that $L^{*}, a^{*}$, and $b^{*}$ values of beetroot puree packed in polymeric films with different oxygen transmission rates decreased during storage at $7^{\circ} \mathrm{C}$, and the changes of overall color difference $(\Delta E)$ of beetroot puree were found to follow the zero-order reaction kinetics. In a study by Narkprasom et al. [2012], the first-order kinetics was reported for the degradation of Hunter $a$ value of Djulis extract (Chenopodium formosanum Koidz.) in model systems containing various ethanol concentrations $(0 \%-60 \%)$ during storage at $20-50^{\circ} \mathrm{C}$. Similarly, Chandran et al. [2014] reported that the degradation of Hunter $a / b$ values of beetroot at $50-120^{\circ} \mathrm{C}$ in an isothermal heating condition followed the first-order kinetics.

\section{Activation energy $\left(E_{\mathrm{a}}\right)$ and temperature quotient $\left(Q_{10}\right)$ values of betalain degradation and changes of the color parameters of the stored yogurts}

The temperature dependency of the betalain degradation and color changes in the yogurt samples were expressed by $E_{\mathrm{a}}$ and $Q_{10}$ values. The $E_{\mathrm{a}}$ value for the degradation of betalains in the yogurts during storage at $4-20^{\circ} \mathrm{C}$ was $104.9 \mathrm{~kJ} / \mathrm{mol}$, 

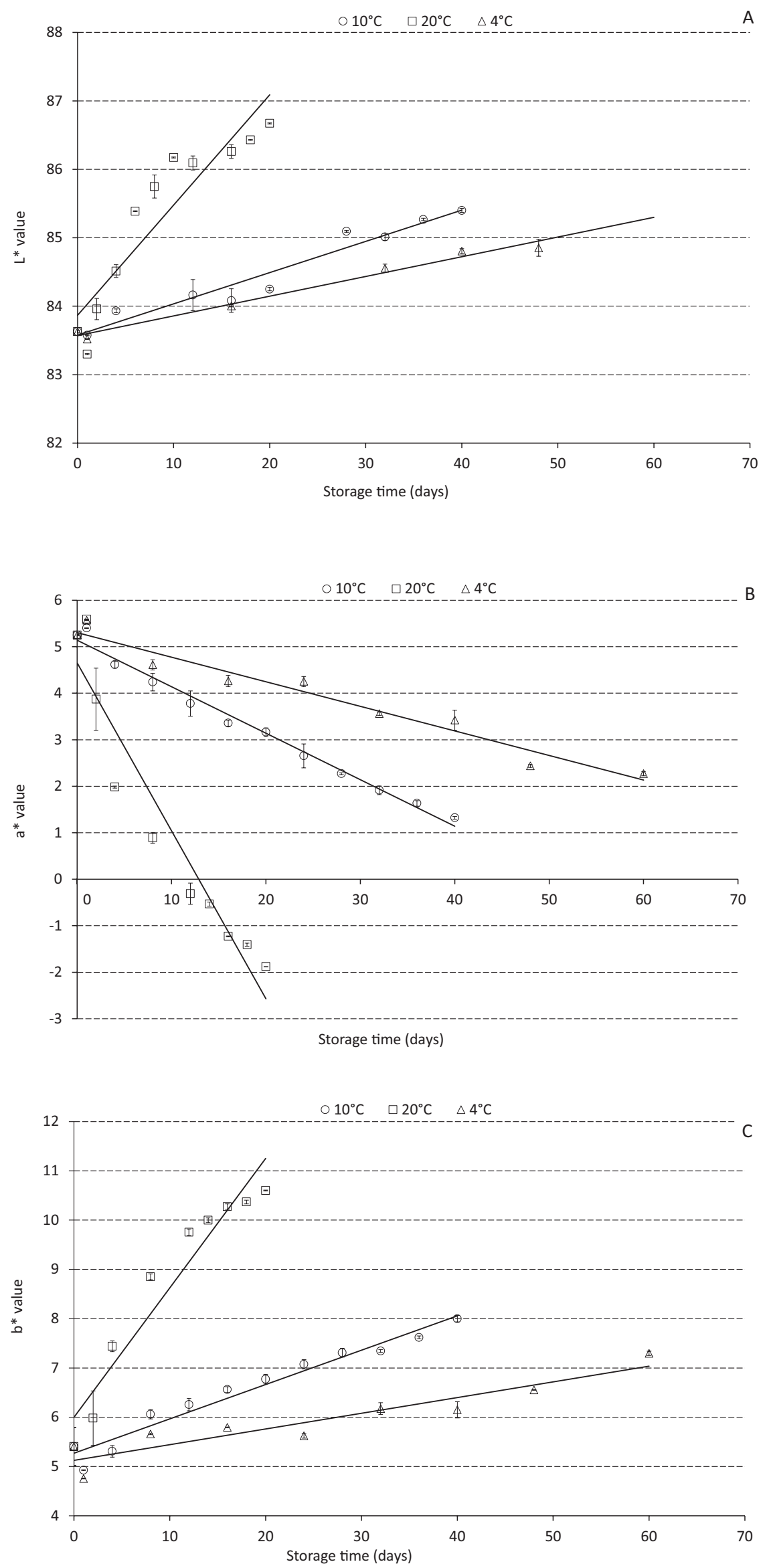

FIGURE 4. Color parameters $-L^{*}-$ lightness (A), $a^{*}$ - redness (B), and $b^{*}-$ yellowness $(\mathrm{C})$ - of the yogurts stored at $4-20^{\circ} \mathrm{C}$. The error bars represent the standard error. 
while calculated $Q_{10}$ values were 2.43 and 6.61 at $4-10^{\circ} \mathrm{C}$ and $10-20^{\circ} \mathrm{C}$, respectively (Table 3 ). Based on these results, it can be interpreted that the reaction rate for betalain degradation in the yogurts is more influenced by the temperature change from $10^{\circ} \mathrm{C}$ to $20^{\circ} \mathrm{C}$ compared with the temperature change from $4^{\circ} \mathrm{C}$ to $10^{\circ} \mathrm{C}$. The $E_{\mathrm{a}}$ values denoting the color changes were $67.6,76.5$, and $86.1 \mathrm{~kJ} / \mathrm{mol}$ for $L^{*}$, $a^{*}$, and $b^{*}$ color parameters, respectively. Due to low $E_{\text {a }}$ values, the changes in $L^{*}$ and $a^{*}$ values were more affected by the temperature elevation than $b^{*}$ value. Indeed, $Q_{10}$ values of the changes in $b^{*}$ value were found to be higher than those of $L^{*}$ and $a^{*}$ values (Table 3 ).

Various $E_{\mathrm{a}}$ values for the betalain degradation and color changes in food systems have been reported [Das et al., 2019; Kayın et al., 2019; Siow \& Wong, 2017]. In a study by Siow \& Wong [2017], $E_{\text {a }}$ values were calculated as 92.817 and $82.953 \mathrm{~kJ} / \mathrm{mol}$ for the degradation of betacyanins in red-fleshed dragon fruit (Hylocereus polyrhizus) juice and its concentrate at $25^{\circ} \mathrm{C}, 37^{\circ} \mathrm{C}$, and $45^{\circ} \mathrm{C}$, respectively, and were lower than $E_{\mathrm{a}}$ value observed in the present study. Similarly, Kayin et al. [2019] reported lower $E_{\mathrm{a}}$ values, such as 66.07 and $93.27 \mathrm{~kJ} / \mathrm{mol}$, for betacyanin and betaxanthin degradations in a red beet juice concentrate stored in glass jars at $25-45^{\circ} \mathrm{C}$. Those researchers have also reported $E_{\text {a }}$ values at $23.00,93.28$, and $88.26 \mathrm{~kJ} / \mathrm{mol}$ for $L^{*}, a^{*}$, and $b^{*}$ color parameters, respectively [Kayın et al., 2019]. Similarly to the present findings, Das et al. [2019] reported $E_{\mathrm{a}}$ values such as 119.75 and $125.34 \mathrm{~kJ} / \mathrm{mol}$ for the degradation of betacyanins extracted from red amaranth using water and $50 \%$ ethanol at $\mathrm{pH} 1$ and 3 , respectively, at storage temperatures of $4^{\circ} \mathrm{C}$ and $30^{\circ} \mathrm{C}$. In turn, the $E_{\mathrm{a}}$ value of $37.54 \mathrm{~kJ} / \mathrm{mol}$ was reported by Chandran et al. [2014] for the changes of Hunter $a / b$ value in beetroot heated at $50-120^{\circ} \mathrm{C}$.

\section{Relationships between the $\mathrm{pH}$ value, betalain content,} and color parameter values in yogurts during storage

Unlike anthocyanins, betalains are color-stable in a food matrix in a wide range of $\mathrm{pH}$ values. The maximum $\mathrm{UV}$ absorption and color spectrum of betalains do not change significantly at $\mathrm{pH}$ from 3 to 7 . According to Fu et al. [2020], the optimal stability of betalains was reached at $\mathrm{pH}$ 4-6. In the present study, the $\mathrm{pHs}$ of the yogurts ranged from 4.15 to 4.69 (Figure 1). Therefore, the color stability of betalains in the yogurts could be expected. However, changes in the color parameters were observed during storage (Figure 4). As explained earlier, these results could be related to the type of degradation, molecular interactions of betalains with the structural components of the yogurt matrix, and others factor, such as dissolved oxygen concentration, content of metal cations content, and enzymes, apart from the $\mathrm{pH}$. Moreover, several types of acids and their amounts have different effects on the color of betalains [Khan, 2016]. In the present study, the titratable acidity (g lactic acid/100 g) of the yogurt samples increased gradually during the storage depending on the storage temperature (Table 2).

Synthetic or natural color pigments that are found in foods have different spectral characteristics. The ultraviolet/visible spectra of these compounds are of great importance because they provide valuable information about their
TABLE 4. Multiple linear regression models for $\mathrm{pH}$, betalain content, and color parameters of the yogurts stored at different temperatures.

\begin{tabular}{|c|c|c|c|}
\hline $\begin{array}{c}\text { Temperature } \\
\left({ }^{\circ} \mathrm{C}\right)\end{array}$ & Multiple regression equation & $\mathrm{R}^{2}$ & $P$ value \\
\hline 4 & $\begin{array}{l}\text { Betalain }(\mathrm{mg} / \mathrm{kg})=7.88 L^{*} \\
\quad+88.23 a^{*}+39.40 b^{*} \\
\quad+72.50 \mathrm{pH}-1329\end{array}$ & 97.55 & 0.020 \\
\hline 10 & $\begin{array}{c}\text { Betalain }(\mathrm{mg} / \mathrm{kg})=3.5 L^{*}+ \\
85.30 a^{*}+41.50 b^{*}-7.4 \mathrm{pH}-581\end{array}$ & 98.59 & 0.000 \\
\hline 20 & $\begin{array}{l}\text { Betalain }(\mathrm{mg} / \mathrm{kg})=6.10 L^{*}+ \\
39 a^{*}-12 b^{*}-168 \mathrm{pH}+352\end{array}$ & 72.09 & 0.177 \\
\hline
\end{tabular}

aNumbers in parentheses are $P$ values for regression analysis. $L^{*}$ : lightness, $a^{*}$ : redness, $b^{*}$ : yellowness.

structure and content in products [Sant'Anna et al., 2013; Wrolstad \& Smith, 2017]. Revealing the relationship between the content of color compounds and their spectral properties in foods by using low-cost and fast techniques is essential to make faster decisions in food processing and preservation [Pathare et al., 2013]. In this context, many studies have been conducted based on different foods [Alighourchi \& Barzegar, 2009; Gonçalves et al., 2007; Güneşer, 2016; Humphries et al., 2004; Su et al., 2016].

The relationship between the content of betalains, color parameters, and $\mathrm{pH}$ of the stored yogurts was explored by multiple linear regression and correlation analyses in the present study. Significant fit of regression models was found for the storage temperatures of $4^{\circ} \mathrm{C}$ and $10^{\circ} \mathrm{C}$ with high determination coefficients $\left(\mathrm{R}^{2}=97.55\right.$ and 98.59) (Table 4). This indicates that the developed models have a reasonable predictive power to calculate the betalain content of the yogurts stored at $4-10^{\circ} \mathrm{C}$. The relative weight of the redness $\left(a^{*}\right)$ as a predictor variable had the highest value, followed by yellowness $\left(b^{*}\right)$ in the models. Furthermore, a positive correlation was determined between the content of betalains, $a^{*}$ value, and $\mathrm{pH}$ value, whereas $L^{*}$ and $b^{*}$ values showed a negative correlation with betalain content (Table 5).

These findings show that the effective assessment of betalain content in yogurt can be achieved by studying the color values of $L^{*}, a^{*}, b^{*}$, and $\mathrm{pH}$ instead of time-consuming chromatographic analysis. Similarly, in a previous study [Güneşer, 2016], a negative correlation was found for $L^{*}$ values and betalain contents in milk with a beetroot colorant heated at $70-90^{\circ} \mathrm{C}$. Moreover, a significant positive correlation was observed between chroma values and betalain contents. Liaotrakoon et al. [2013] showed that $a^{*}$ and $b^{*}$ values could be used as criteria to determine the quality of white and red-flesh dragon fruit purees and also that the betalain content of red-flesh dragon fruit purees could be estimated by using the total color change with a high prediction $\left(\mathrm{R}^{2}=0.94\right)$. In another study by Gonçalves et al. [2007], the total anthocyanin content of four different sweet cherry cultivars (Burlat, Saco, Summit, and Van) was reported to negatively correlate with $L^{*}, a^{*}, b^{*}$, chroma, and hue angle values during storage at $1.5^{\circ} \mathrm{C}$ and $15^{\circ} \mathrm{C}$. In turn, Humphries et al. [2004] investigated the relationship between $L^{*}, a^{*}, b^{*}$ values, and lutein and carotene contents in wheat and triticale samples. The positive correlation found between lutein contents and $b^{*}$ values was 
TABLE 5. Coefficients of correlations between $\mathrm{pH}$, betalain content, and color parameters of the stored yogurts.

\begin{tabular}{l|c|c|c|c}
\hline & $\begin{array}{c}\text { Betalain } \\
\text { content }\end{array}$ & $L^{*}$ & $a^{*}$ & $b^{*}$ \\
\hline$L^{*}$ & -0.834 \\
& $(0.001)^{\mathrm{a}}$ & & & \\
$a^{*}$ & 0.960 & 0.853 & & \\
& $(0.001)$ & $(0.001)$ & & \\
$b^{*}$ & -0.935 & 0.832 & -0.990 & \\
& $(0.001)$ & $(0.001)$ & $(0.00)$ & \\
$\mathrm{pH}$ & 0.720 & -0.651 & 0.727 & -0.692 \\
& $(0.001)$ & $(0.001)$ & $(0.001)$ & $(0.001)$ \\
\hline
\end{tabular}

a Numbers in parentheses are $P$ values determined for correlation analysis. $L^{*}$ : lightness, $a^{*}$ : redness, $b^{*}$ : yellowness.

stronger for durum wheat than that determined for other wheat varieties. In contrast, it was found that carotene and lutein contents were weakly correlated with $L^{*}$ and $a^{*}$ values in wheat and triticale samples. It can generally be concluded that such color parameters as $L^{*}, a^{*}$, and $b^{*}$ are directly related to pigments present in food items. Thus, the color analysis is a useful tool to determine the content of natural pigments of various food items at various processing stages. Sensory color analyses should also be performed in this respect along with instrumental color and chromatographic analyses.

\section{CONCLUSION}

This study evaluated the stability of beetroot betalains in yogurts during storage. The $\mathrm{pH}$ values of yogurts containing the beetroot extract decreased during the storage, and the decrease was the highest at $20^{\circ} \mathrm{C}$. First-order kinetics were reported for the degradation of betalains in yogurts stored at $4^{\circ} \mathrm{C}, 10^{\circ} \mathrm{C}$, and $20^{\circ} \mathrm{C}$. Moreover, changes in $L^{*}, a^{*}$, and $b^{*}$ values followed the zero-order kinetics. Storage temperatures had the least effect on $L^{*}$ value followed by $a^{*}$ value of color of the yogurts. It was observed that the developed multiple linear regression models had a reasonable predictive power to calculate the betalain content of yogurt samples stored at $4-20^{\circ} \mathrm{C}$. The highest value as a predictor variable was obtained for $a^{*}$ in the models. Further studies should be performed by considering the matrix effect on natural pigments, color parameters, and sensory color properties. All obtained data can be analyzed further using advanced statistical methods to reveal the relationship between color value and natural pigments in food systems.

\section{RESEARCH FUNDING}

This study was supported by The Scientific Research Fund of Uşak University (2014/MF020).

\section{ACKNOWLEDGEMENTS}

The author would like to thank NANTE Chemical Com. (Istanbul, Turkey) for providing the beetroot extract. The author would also like to thank Danem Dairy Company (Isparta, Turkey) for providing the yogurt starter culture.

\section{CONFLICT OF INTERESTS}

The author declares that there is no conflict of interest.

\section{ORCID ID}

O. Guneser https://orcid.org/0000-0002-3927-4469

\section{REFERENCES}

1. Alighourchi, H., Barzegar, M. (2009). Some physicochemical characteristics and degradation kinetic of anthocyanin of reconstituted pomegranate juice during storage. Journal of Food Engineering, 90, 179-185.

https://doi.org/10.1016/j.jfoodeng.2008.06.019

2. Amchova, P., Kotolova, H., Ruda-Kucerova, J. (2015). Health safety issues of synthetic food colorants. Regulatory Toxicology and Pharmacology, 73, 914-922.

https://doi.org/110.1016/j.yrtph.2015.09.026

3. Azeredo, H.M.C. (2009). Betalains: properties, sources, applications, and stability - a review. International Journal of Food Science \& Technology, 44, 2365-2376.

https://doi.org/10.1111/j.1365-2621.2007.01668.x

4. Bárta, J. Bártova, V., Šindelková, T., Jarošová, M., Linhartová, Z., Mráz, J., Bedrníček, J., Smertana, P., Samková, E., Laknerová, I. (2020). Effect of boiling on colour, contents of betalains and total phenolics and on antioxidant activity of colourful powder derived from six different beetroot (Beta vulgaris L. var. conditiva) cultivars. Polish Journal of Food and Nutrition Sciences, 70(4), 377-385.

https://doi.org/10.31883/pjfns/128613

5. Bradley, J.R.L., Arnold, J.E., Barbano, D.M., Semerad, R.G., Smith, D.E., Vines, B.K. (1992). Chemical and physical methods. In R. Marshal (Ed.), Standard Methods for the Examination of Dairy Products. American Public Health Association, Washington, DC, USA, pp. 433-531.

6. Caldas-Cueva, J.P., Morales, P., Ludena, F., Betalleluz-Pallardel, I., Chirinos, R., Noratto, G., Campos, D. (2016). Stability of betacyanin pigments and antioxidants in ayrampo (Opuntia soehrensii britton and rose) seed extracts and as a yogurt natural colorant. Journal of Food Processing and Preservation, 40, 541-549. https://doi.org/10.1111/jfpp.12633

7. Chandran, J., Nisha, P., Singhal, R.S., Pandit, A.B. (2014). Degradation of colour in beetroot (Beta vulgaris L.): a kinetics study. Journal of Food Science and Technology, 51, 2678-2684. https://doi.org/10.1007/s13197-012-0741-9

8. Czyżowska, A., Klewicka, E., Libudzisz, Z. (2006). The influence of lactic acid fermentation process of red beet juice on the stability of biologically active colorants. European Food Research and Technology, 223(1), 110-116.

https://doi.org/10.1007/s00217-005-0159-y

9. Das, M., Saeid, A., Hossain, M.D.F., Jiang, G.H., Eun, J.B., Ahmed, M. (2019). Influence of extraction parameters and stability of betacyanins extracted from red amaranth during storage. Journal of Food Science and Technology, 56, 643-653. https://doi.org/10.1007/s13197-018-3519-x

10. Delgado-Vargas, F., Jiménez, A.R., Paredes-López, O. (2000). Natural pigments: carotenoids, anthocyanins, and betalains - 
characteristics, biosynthesis, processing, and stability. Critical Reviews in Food Science and Nutrition, 40, 173-289.

https://doi.org/10.1080/10408690091189257

11. Farinde, E.O., Adesetan, T.O., Obatolu, V.A., Oladapo, M.O. (2009). Chemical and microbial properties of yogurt processed from cow's milk and soymilk. Journal of Food Processing and Preservation, 33(2), 245-254.

https://doi.org/10.1111/j.1745-4549.2008.00336.x

12. Fernández-López, J.A., Angosto, J.M., Giménez, P.J., León, G. (2013). Thermal stability of selected natural red extracts used as food colorants. Plant Foods for Human Nutrition, 68(1), 11-17. https://doi.org/10.1007/s11130-013-0337-1

13. Fu, Y., Shi, J., Xie, S.Y., Zhang, T.Y., Soladoye, O.P., Aluko, R.E. (2020). Red beetroot betalains: perspectives on extraction, processing, and potential health benefits. Journal of Agricultural and Food Chemistry, 68(42), 11595-11611.

https://doi.org/10.1021/acs.jafc.0c04241

14. Galaffu, N., Bortlik, K., Michel, M. (2015). An industry perspective on natural food colour stability. In: M.J. Scotter(Ed.), Colour Additivies for Foods and Beverages. Woodhead Publishing Series in Food Science, Technology and Nutrition, Oxford, UK, pp. 91-130. https://doi.org/10.1016/B978-1-78242-011-8.00005-2

15. Gandía-Herrero, F., Simon-Carillo, A., Escribano, J., Garcia-Carmona, F. (2012). Determination of beet root betanin in dairy products by high-performance liquid chromatography (HPLC). Journal of Chemical Education, 89, 660-664. https://doi.org/10.1021/ed200397q

16. Gandía-Herrero, F., Escribano, J., García-Carmona, F. (2010). Structural implications on color, fluorescence, and antiradical activity in betalains. Planta, 232(2), 449-460.

https://doi.org/10.1007/s00425-010-1191-0

17. Gengatharan, A., Dykes, G.A., Choo, W.S. (2017). The effect of pH treatment and refrigerated storage on natural colourant preparations (betacyanins) from red pitahaya and their potential application in yoghurt. LWT - Food Science and Technology, 80, 437-445. https://doi.org/10.1016/j.Iwt.2017.03.014

18. Gengatharan, A., Dykes, G.A., Choo, W.S. (2015). Betalains: Natural plant pigments with potential application in functional foods. LWT - Food Science and Technology, 64, 645-649. https://doi.org/10.1016/j.Iwt.2015.06.052

19. Gonçalves, B., Silva, A.P., Moutinho Pereir, J.M., Bacelar, E.A. (2007). Effect of ripeness and postharvest storage on the evolution of colour and anthocyanins in cherries (Prunus avium L.). Food Chemistry, 103, 976-984.

https://doi.org/10.1016/j.foodchem.2006.08.039

20. Güneşer, O. (2016). Pigment and color stability of beetroot betalains in cow milk during thermal treatment. Food Chemistry, 196, 220-227. https://doi.org/10.1016/j.foodchem.2015.09.033

21. Herbach, K.M., Maier, C., Stinzing, F.C., Carle, R. (2007). Effects of processing and storage on juice colour and betacyanin stability of purple pitaya (Hylocereus polyrhizus) juice. European Food Research and Technology, 224, 649-658. https://doi.org/10.1007/s00217-006-0354-5

22. Herbach, K.M., Stintzing, F.C., Carle, R. (2006). Betalain stability and degradation - astructural and chromatic aspects. Journal of Food Science, 71, R41-R50.

https://doi.org/10.1111/j.1750-3841.2006.00022.x
23. Herbach, K.M., Stintzing, F.C., Carle, R. (2004). Impact of thermal treatment on color and pigment pattern of red beet (Beta vulgaris L.) preparations. Journal of Food Science, 69(6), C491-C498. https://doi.org/10.1111/j.1365-2621.2004.tb10994.x

24. Humphries, J.M., Graham, R.D., Mares, D.J. (2004). Application of reflectance colour measurement to the estimation of carotene and lutein content in wheat and triticale. Journal of Cereal Science, 40, 151-159. https://doi.org/10.1016/j.jcs.2004.07.005

25. ISO-CIE (2008). Colorimetry, part 4: CIE $1976 L^{*} a^{*} b^{*}$ colour space, 11664-4.

26. Karangutkar, A.V., Ananthanarayan, L. (2021). Evaluating the effect of additives on stability of betacyanin pigments from Basella rubra in a model beverage system during storage. Journal of Food Science and Technology, 58, 1262-1273. https://doi.org/10.1007/s13197-020-04635-8

27. Kayın, N., Atalay, D., Akçay, T.T., Erge, H.S. (2019). Color stability and change in bioactive compounds of red beet juice concentrate stored at different temperatures. Journal of Food Science and Technology, 56, 5097-5106. https://doi.org/10.1007/s13197-019-03982-5

28. Khan, M.I. (2016). Stabilization of betalains: A review. Food Chemistry, 197, 1280-1285.

https://doi.org/10.1016/j.foodchem.2015.11.043

29. Liaotrakoon, W., De Clercq, N., Hoed, V.V., de Walle, D.V., Lewille, B., Dewettinck, K. (2013). Impact of thermal treatment on physicochemical, antioxidative and rheological properties of white-flesh and red-flesh dragon fruit (Hylocereus spp.) purees. Food and Bioprocess Technology, 6, 416-430.

https://doi.org/10.1007/s11947-011-0722-4

30. Manchali, S., Murthy, K.N.C., Nagaraju, S., Neelwarne, B. (2013). Stability of betalain pigments of red beet. In B. Neelwarne (Ed.), Red Beet Biotechnology, Springer Science+Business Media, Springer, pp. 55-74.

https://doi.org/10.1007/978-1-4614-3458-0_3

31. Martins, N., Roriz, C.L., Morales, P., Barros, L., Ferreire, C.F.R.I. (2016). Food colorants: challenges, opportunities and current desires of agro-industries to ensure consumer expectations and regulatory practices. Trends in Food Science \& Technology, 52, 1-15. https://doi.org/10.1016/j.tifs.2016.03.009

32. Moreno, D.A., Garcia-Viguera, C., Gil, J.I., Gil-Izquierdo, A. (2008). Betalains in the era of global agri-food science, technology and nutritional health. Phytochemistry Reviews, 7, 261-280. https://doi.org/10.1007/s11101-007-9084-y

33. Moreno, M., Betancourt, M., Pitre, A., Garcia, D., Belen, D., Medina, C. (2007). Evaluación de la estabilidad de bebidas cítricas acondicionadas con dos fuentes naturales de betalaínas: tuna y remolacha. Bioagro, 19, 149-159 (in Spanish; English abstract).

34. Naderi, N., Ghazali, H.M., Hussin, S.A., Amid, M., Manap, M.Y.A. (2012).Characterization and quantification of dragon fruit (Hylocereus polyrhizus) betacyanin pigments extracted by two procedures. Pertanika Journal of Tropical Agricultural Science, 35, 33-40.

35. Narkprasom, K., Wang, S.P., Hsiao, S.M., Tsai, P.J. (2012). Kinetics of color loss of Djulis (Chenopodium formosanum Koidz.) extracts during storage in different concentrations of alcohol and temperature. APCBEE Procedia, 2, 32-36. https://doi.org/10.1016/j.apcbee.2012.06.007 
36. Özoğlu, Ö., Şaşmazer, R.Ç., Erginkaya, Z., Korukoğlu, M. (2020). Surveying production and characteristics of homemade yogurt by using a commercial probiotic culture. Glda - The Journal of Food, 45, 814-824.

https://doi.org/10.15237/gida.GD20028

37. Pathare, P.B., Opara, U.L., Al-Said, F.A.J. (2013). Colour measurement and analysis in fresh and processed Foods: a review. Food and Bioprocess Technology, 6, 36-60.

https://doi.org/10.1007/s11947-012-0867-9

38. Reyes, L.F., Cisneros-Zevallos, L. (2007). Degradation kinetics and colour of anthocyanins in aqueous extracts of purpleand red-flesh potatoes (Solanum tuberosum L.). Food Chemistry, $100,885-894$.

https://doi.org/10.1016/j.foodchem.2005.11.002

39. Roidoung, S., Dolan, K.D., Siddiq, M. (2017). Estimation of kinetic parameters of anthocyanins and color degradation in vitamin $\mathrm{C}$ fortified cranberry juice during storage. Food Research International, 94, 29-35.

https://doi.org/10.1016/j.foodres.2017.01.013

40. Sant'Anna, V., Gurak, P.D., Ferreira Marczak, L.D., Tessaro, I.C. (2013). Tracking bioactive compounds with colour changes in foods - a review. Dyes and Pigments, 98, 601-608. https://doi.org/10.1016/j.dyepig.2013.04.011

41. Shah, N.P. (2000). Probiotic bacteria: selective enumeration and survival in dairy foods. Journal of Dairy Science, 83, 894-907. https://doi.org/10.3168/jds.S0022-0302(00)74953-8

42. Sheskin, D. (2004) Handbook of Parametric and Nonparametric Statistical Procedures. 3rd edition. Chapman and Hall/CRC Press, New York, USA, pp. 667-727.

https://doi.org/10.1201/9781420036268

43. Sigurdson, G.T., Tang, P., Giusti, M.M. (2017). Natural colorants: food colorants from natural sources. Annual Review of Food Science and Technology, 8, 261-280. https://doi.org/10.1146/annurev-food-030216-025923

44. Siow, L.F., Wong, Y.M. (2017). Effect of juice concentration on storage stability, betacyanin degradation kinetics, and sensory acceptance of red-fleshed dragon fruit (Hylocereus polyrhizus) juice. International Journal of Food Properties, 20, 623-632.

https://doi.org/10.1080/10942912.2016.1172086

45. Sonar, C.R., Rasco, B., Tang, J., Sablani, S.S. (2019). Natural color pigments: oxidative stability and degradation kinetics during storage in thermally pasteurized vegetable purees. Journal of the Science of Food and Agriculture, 99, 5934-5945.

https://doi.org/10.1002/jsfa.9868

46. Su, G., Songming, Z., Menglong, X., Hosahalli, S.R., Lin, Y., Yu, Y. (2016). Pressure degradation kinetics of anthocyanin pigment and visual color of chinese bayberry juice. International Journal of Food Properties, 19, 443-453.

https://doi.org/10.1080/10942912.2015.1038562

47. Tamime, R., Robinson, R.K. (Eds.) (2007). Yoghurt: Science and Technology. 3rd edition. Woodhead Publishing Limited, CRC Press, Cambridge, UK, pp. 13-161.

https://doi.org/10.1533/9781845692612.13

48. TFC. (2013). Turkish Food Codex Regulation on Food Additives. Regulation No. 28693. Ankara: Republic of Turkey Ministry of Agriculture and Forestry.

49. Tobolková, B., Polovka, M., Dasko, L., Belajova, E., Durec, J. (2020). Evaluation of qualitative changes of apple-beetroot juice during long-term storage at different temperatures. Journal of Food Measurement and Characterization, 14, 3381-3388. https://doi.org/10.1007/s11694-020-00592-0

50. van Boekel, M.A.J.S. (2008). Kinetic modeling of food quality: a critical review. Comprehensive Reviews in Food Science and Food Safety, 7, 144-158. https://doi.org/10.1111/j.1541-4337.2007.00036.x

51. Wrolstad, R.E., Smith, D.E. (2017). Color analysis. In S.S Nielsen (Ed.), Food Analysis, Cham: Springer International Publishing, pp. 545-555.

https://doi.org/10.1007/978-3-319-45776-5_31

52. Yiğit, K., Guneser, O., Yüceer, Y. (2011). Farklı ticari kültürler kullanılarak üretilen yağsız yoğurtların fiziksel kimyasal ve duyusal özellikleri. Hasad Gıda, 26, 30-35 (in Turkish). 
